\title{
ViolenCE AND NARCissism: A Frommian Perspective on Destructiveness under Authoritarianism ${ }^{1}$
}

\author{
LeOnidas K. Cheliotis
}

Abstract. This article offers a sympathetic appraisal of Erich Fromm's concept of narcissism as it relates to the emergence, sustenance, and resolution of authoritarian violence. The discussion is first placed within the methodological debate over the analytic operations that are required for an adequate understanding of authoritarian violence, explaining why a psychoanalytic perspective is necessary. The focus then shifts to Fromm's take on the Freudian concept of narcissism, before proceeding to explore in some depth his account of the symbolic mechanisms and contextual climate that must combine in practice in order for narcissistic energies to be channeled into authoritarianism and violence. Attention in this regard is paid both to the populace and governing elites. The article concludes with a short exposition of Fromm's notion of benign narcissism, from its specific content to the conditions of its possibility.

Keywords: narcissism; violence; destructiveness; authoritarianism; Erich Fromm

Résumé. Cet article offre une évaluation bien disposée de la conceptualisation du narcissisme selon Erich Fromm et du rapport de cette notion à l'émergence, la nourriture et la résolution de la violence autoritaire. L'analyse est d'abord située dans le débat méthodologique sur les opérations analytiques requises pour une compréhension adéquate de la violence autoritaire, en expliquant pourquoi une perspective psychanalytique est nécessaire. Le point d'attention puis se déplace à l'approche du Fromm sur le concept Freudien du narcissisme, avant de procéder à explorer en quelque détail son explication des mécanismes symboliques et du climat contextuel qui doivent combiner en réalité afin que les énergies narcissiques soient acheminées au autoritarisme et à la violence. À cet égard, d'attention est donnée à la fois à la populace et aux élites gouvernantes. L'article conclut avec une exposition brève de la notion du narcissisme bénin de Fromm, de son contenu spécifique aux conditions de sa possibilité.

Mots clés: narcissisme; violence; effet destructeur; autoritarisme; Erich Fromm

1. Acknowledgements: For their helpful and encouraging comments, I am grateful to Sappho Xenakis, Kevin Haggerty, and the anonymous reviewers of the journal. Rodanthi Christofaki kindly translated the English abstract of the article into French, and Laura Botsford skillfully edited the article according to the journal's conventions. 
In his limited but influential writings on narcissism, Freud closely associated the concept with the supposed propensity of humans towards authoritarian domination, including destructiveness. This article offers a sympathetic appraisal of Erich Fromm's revisionist elaboration of Freud to account for narcissism, not just as an antecedent of authoritarian domination and violence, but also as compatible with humanism. Rather than putting forth a new orthodoxy, the aim is to uncover an unduly ignored or undermined perspective of the unconscious and its relation to the outer sociopolitical world. Fromm is not alone in suggesting revisions to Freudian depth psychology (see McLaughlin 2001), nor are revisions to Freudian depth psychology the sole avenues into the social and political dimensions of narcissism (see, e.g., Benjamin 1988; Chodorow 1978). However, Fromm is distinct in painstakingly correcting and developing Freud's tradition in general, and his conception of narcissism in particular, against the background of theoretical insights and empirical findings drawn from political sociology, anthropology, and history (see Cheliotis 2011). ${ }^{2}$

For Fromm, narcissism is a constituent component of authoritarian domination, which may simultaneously assume passive and active forms. Just as submission to external authorities stems from fear of failure and loss in the face of the dangers and responsibilities inherent in freedom, so power over others serves to reaffirm feelings of personal strength and superiority (Fromm, 1994 [1941]; 1984 [1973]). What renders people susceptible to authoritarian domination, Fromm clarifies, is not their narcissistic inclinations as such. It is rather the desire to uphold or improve one's social standing according to the requirements of given cultural milieus and the overarching "metastructures" of politics and the economy; indeed, Fromm applies this argument to governing elites as much as the populace at large. As he also underscores, any individual supportive of authoritarianism is bound to encounter the narcissistic problem of maintaining a clear conscience, a problem which, as he explains, is resolved through the use of legitimation techniques that emerge from the same milieus and "metastructures" as those defining what comprises social distinction. Crucially, the identification of sociopolitical and socioeconomic environments as central to the growth of authoritarianism allows Fromm not only to theorize a resolution, but to do so by breaking with the conventional, pathologizing conceptions of narcissism, proposing that the route out of states of domination passes through man's own need for narcissistic relatedness. ${ }^{3}$ The Frommian vision is a world driven by

2. For similar and more recent attempts to employ psychoanalysis (often, but not always, of Freudian inspiration) in social science, see, amongst others, Chancer (1992); Craib (1990); Scheff (2006); Smelser (1998).

3. Fromm uses "man" and the male pronoun to refer to both males and females. Outside quotations, I have chosen to use the male and female pronouns interchangeably. 
the moral philosophy of humanism, which can uniquely bind individuals in harmony and love without stifling individuality and difference - a world where narcissism acquires benign forms.

With a view to highlighting the longstanding and continuing relevance of Frommian scholarship to a range of epistemological and substantive debates on authoritarianism and beyond, it is either contrasted or combined below with various pertinent writings of other thinkers. Whilst Fromm might not have found all that follows familiar, the hope is that he could have recognized it as being in broad accord with his perspective. After all, Fromm himself often treated his work as a modus operandi, a method by which to pose and solve problems in divergent temporal and spatial contexts, helping to discover general principles without disregard for specificities.

I begin by placing the discussion within the methodological debate over the analytic operations that are required for an adequate understanding of authoritarian violence, explaining why a psychoanalytic perspective is necessary. Next, I briefly examine Fromm's take on the Freudian concept of narcissism, before proceeding to explore in some depth his account of the symbolic mechanisms and contextual conditions that must combine in practice for narcissistic energies to be channeled into the emergence and sustenance of authoritarianism and violence. The focus in this regard is first on the populace and then on governing elites. The article concludes with a short exposition of Fromm's concept of benign narcissism, both in terms of its specific content and the conditions of its possibility.

\section{Epistemological Reflections on Authoritarian Violence}

Thematically speaking, this article is situated squarely within the age-old debate over how to explain that people, objectively failing their cherished moral values and even their basic material interests, consciously consent to the exercise of violence against given others under conditions of authoritarianism. In line with Fromm (1994 [1941]), an authoritarian attitude is taken to entail both the "masochistic" desire to submit to authoritarian regimes and the "sadistic" urge to dominate over others - be it through submitting to, or enacting violence on behalf of, authoritarian regimes. ${ }^{4} \mathrm{~A}$ further question addressed in this article, albeit more briefly, concerns authoritarian elites and their own objective failure to

4. Whilst, as we shall see later, Fromm mainly has in mind the totalitarian regimes in Europe during the first half of the 20th century, he is primarily concerned with the symbolic mechanisms and contextual conditions that give rise to authoritarian sentiments, rather than the specific structural components of authoritarian regimes as such. 
meet personal and in-group standards of rationality and morality in their governing behaviour.

Both themes necessarily involve examining how individuals come to perceive themselves and their broader social world in ways that legitimate prima facie illegitimate social orders. This is because all individuals, regardless of their position within social space, continuously assess the rationality and morality of their actions; indeed, no action may be undertaken unless individuals deem it accordant with their principles of rationality and morality (see further Vetlesen 1994). Accounting for misperceptions of factually illegitimate social orders as legitimate is essentially part of the broader project of accounting for the forces that deprive subjects of their very subjectivity in the sense of incorporating them ideologically (see further Cheliotis 2010a). Yet the analytic operations one must perform to identify these forces are an issue fraught with disagreement. There is no consensus as to whether one should start from the fuzzy experience of life as lived and articulated by individuals, or, conversely, from the crude tangible indices of the world that surrounds and stifles them. Should one, perhaps, grant epistemological priority to some alternative standpoint?

So-called "subjectivism" or "constructivism," propounded most notably by Harold Garfinkel (1967) and Herbert Blumer (1969), suggests that we conduct open-ended inductions from individual patterns of thought. Namely, that we begin by looking at the ways in which people reflect upon themselves, and then proceed to examine how these reflections are indicative of particular social and cultural contexts. From this standpoint, for instance, political rhetoric is no more than a framework within which the individual thinks and acts - it is, in fact, the latter who lends meaning and life to the former, not vice versa. But, as Wacquant (1992:11) comments, to give voice to subjects as the initial step towards accounting for the breadth and "weight" of impositions on the self violates the first and widely accepted principle of Émile Durkheim's "sociological method": the systematic eradication of preconceptions, of "the fallacious ideas that dominate the mind of the layman, the yoke of these empirical categories, which from long continued habit have become tyrannical" (Durkheim 1964 [1893]:32). Subjectivism, in other words, is unduly optimistic because overly agential in its conceptualization of selfhood.

By contrast, so-called "objectivists" or "structuralists," from Durkheim to Claude Lévi-Strauss (1966 [1962]), set out to define the structural forces that influence individual thought and conduct. To this goal, they study society "from the outside," from the viewpoint of institutions and more or less separately from individuals and groups, as if the former 
wholly and permanently control the perceptions of the latter. Thus, if subjectivism exaggerates the agential powers of individuals, objectivism reifies structures "by treating them as autonomous entities endowed with the ability to 'act' in the manner of historical agents" (Wacquant 1992:8). At the same time, the objectivist perspective leaves us in the dark as to why particular subjects come to locate themselves in particular ways within particular rhetorics, political or otherwise.

More fruitfully, such thinkers as Pierre Bourdieu and Stuart Hall have promoted a synthesis of subjectivism and objectivism, constructivism and structuralism. Bourdieu argues that, whilst the objectivist rejection of individual preconceptions must always predate the apprehension of the world from the subjectivist viewpoint, one should not miss or underestimate the fact that individuals always play a role in the construction of reality-they 'make meaningful the world which makes them' (Wacquant 1992:7). Thus, Bourdieu suggests, society should be studied as comprising a "double objectivity":

the "objectivity of the first-order", which is constituted by the distribution of material resources and means of appropriation of socially scarce goods and values,... [and the] "objectivity of the second order," in the form of systems of classification, the mental and bodily schemata that function as symbolic templates for the practical activities - conduct, thoughts, feelings, and judgments - of social agents. (Wacquant 1992, original emphasis)

Approaching the two types of objectivity as standing in a relationship of mutual constitution to one another, Bourdieu speaks of socially constructed perceptive "dispositions" that emerge to obscure the arbitrary bases of inequality. What makes people susceptible to acquiring and enacting particular perceptive dispositions, even against their own interests and values, is that perceptive dispositions subtly express established positions within social space, which they thereby consolidate (see, e.g., Bourdieu 1989; 2005).

Bourdieu's model is echoed in the "middle ground" perspective suggested by Hall. To Hall, whilst symbolic mechanisms such as discourse help leave the imprint of power on individual thought and action - an observation which carries the methodological implication that they are best understood through the lenses of subordinates themselves - the imperatives of symbolic communication provide much narrower and more substantive limits on individual thought and action than subjectivists would ever have us believe. Whence the need to start by adopting an objectivist perspective, soon followed by locating 
ourselves in the position from which the discourse makes most sense, and thus becom[ing] its "subjects" by "subjecting" ourselves to its meanings, power, and regulation. All discourses, then, construct subject positions, from which alone they make sense. (Hall 1997:56, emphasis in original)

The problem with such syntheses of objectivism and subjectivism is that they fail to take count of the fact that particular perceptive dispositions or ways of sense-making are more desirable in themselves than others. As a consequence, they ultimately fail to explain why individuals in disparate social positions may be equally prone to share the same perceptive stance (see Cheliotis 2011). To put the point differently, Bourdieu and Hall do well in describing the social processes through which existing power dynamics are reproduced, but fall short of revealing the deeper, psychological reasons why existing power dynamics came to be produced in the first place or why mechanisms of their reproduction so often meet with success (Steinmetz 2005; 2006). The emerging gap may only be filled through engaging with psychoanalytic insights into the innate human dispositions with which symbolic constructs need to resonate if they are to prove effective. Indeed, if instincts are, to use the fashionable phrase, what is always there already, they should be accorded chronological primacy in the analytic process, even though attention needs then to shift to their development under the influence of sociopolitical and socioeconomic forces.

In lieu of an exhaustive excursus into psychoanalytic scholarship on the complex linkages between the individual, her society, and politics an excursus that would at any rate be impossible in the space of an article (see Layton et al. 2006) - I turn below to Erich Fromm and his theory of narcissism as it relates specifically to the emergence and sustenance of authoritarianism and violence.

\section{Signposts on the Concept of Narcissism}

Narcissism, it has been said, is "the metaphor of the human condition"such is its centrality to everyday life, especially in modern and contemporary Western societies, and so great its use as a descriptive term, even in lay parlance (Sugerman 1976:12). Only rarely, if ever, are Fromm's extensive and insightful writings on the subject discussed in the literature, be it psychoanalytical or sociological, scholarly or mere pop (see, e.g., Jacoby 1985; Morrison 1989; Schwartz-Salant 1982; Gaitanidis and Curk 2007; Elliott and Lemert 2006; Lowen 1997; Sennett 1977). Worse still, on several of those few occasions where Fromm's work does register, readers are presented with a highly distorted picture of its scope and 
depth. In his best-seller The Culture of Narcissism, for instance, Christopher Lasch refers to Fromm's The Heart of Man and the discussion of "individual" and "social narcissism" elaborated therein as

appropriately published in a series of books devoted to "Religious Perspectives," [because it] provides an excellent example of the inclination, in our therapeutic age, to dress up moralistic platitudes in psychiatric garb. (Lasch 1979:31)

According to Lasch, that Fromm is "eager to sermonise about the blessings of brotherly love" leads him to commit a series of fundamental analytical and substantive mistakes: from confusing "cause and effect, attributing to a cult of privatism developments that derive from the disintegration of public life," to using "the term narcissism so loosely that it retains little of its psychological content," to describing narcissism "simply as the antithesis of that watery love for humanity (disinterested 'love for the stranger')," to "equating narcissism with everything selfish and disagreeable [and thereby ignoring] historical specificity," to failing to "explore any of the character traits associated with pathological narcissism, which in less extreme form appear in such profusion in the everyday life of our age: dependence on the vicarious warmth provided by others combined with a fear of dependence, a sense of inner emptiness, boundless repressed rage, and unsatisfied oral cravings," to missing "what might be called the secondary characteristics of narcissism: pseudo self-insight, calculating seductiveness, nervous, self-deprecatory humour" (Lasch 1979:31-33). As a consequence of all this, Lasch tells us, Fromm deprives himself of

any basis on which to make connections between the narcissistic personality type and certain characteristic patterns of contemporary culture, such as the intense fear of old age and death, altered sense of time, fascination with celebrity, fear of competition, decline of the play spirit, deteriorating relations between men and women. (Lasch 1979:31-33)

Sidestepping the fallacious attachment to the notion that theorizing in the social sciences is possible without a moral perspective, it may be said that Lasch subjects the essence of Fromm's work to a Kafkaesque metamorphosis, as it were. This will become evident throughout the remainder of this article (see also Maccoby 1981:43-46), but to start here with the obvious, as suggested in the very subtitle of The Heart of Man - Its Genius for Good and Evil - Fromm's intention is to address as open-mindedly as possible the issue of whether humans are basically evil and corrupt, or, alternatively, good and perfectible. "There is no denying that each man goes forward in the direction he has chosen: 
that of life or that of death; that of good or that of evil," he concludes (Fromm 1964:23); if we are adequately to explain why history continues to be written in blood, however, then we need to engage in an up-close analysis of the situational factors under the influence of which a majority of average men choose the direction of death and evil over that of life and good; why they proceed to act like hungry wolves towards their weaker fellow men, even if it is in their nature to behave like harmless sheep. That mass phenomenon of solipsism and xenophobia which Fromm terms "malignant narcissism" may be the key here. Not that

wars are primarily the result of psychological forces... But just as one needs weapons in order to fight a war, one needs the passions of hate, indignation, destructiveness, and fear in order to get millions of people to risk their lives to become murderers. (Fromm 1964:22)

Narcissus, it may be recalled, was a legendary young man of renowned beauty who turned down the love of the nymph Echo. Such was his callousness that the Gods vowed to punish Narcissus by causing him to fall in love with the reflection of his very own image in the water of a mountain pool. His end was tragic: yearning to embrace the mirror image, he fell into the water and drowned. A phalanx of psychoanalysts, from Freud and Fromm to Kohut and Kernberg, have drawn inspiration from the tale of Narcissus to explore such distinct phenomena as love, creativity, castration fear, inferiority, shame, lack of empathy, rage, and sadism, and also for the understanding of mass psychoses, particularly that of consensual submission to authoritarian regimes. For his part, Fromm takes the theoretical lead from Freud and his distinction between "primary" and "secondary" narcissism in particular.

Primary narcissism, according to Freud, occurs when the libido is exclusively directed to the self. Infants, to instance an ideal-typical case, are born in the delusion that the whole world revolves around them. Although narcissistic delusions never fully disappear, they may be reduced in the process of maturation to the socially accepted minimum. If, on the other hand, narcissistic delusions go unchecked, they may seriously distort rational judgment and give rise to overly favourable evaluations of the self as compared to others, alongside extreme anxieties of being found weak and worthless. Such states Freud describes in pathological terms, as manifestations of "secondary narcissism." Fromm accepts the general premise of "secondary narcissism" as developed by Freud, and elaborates that it should not be equated with selfishness or egotism. For, unlike narcissists, selfish or egotistical persons do not necessarily overevaluate themselves, nor do they always lack awareness of the social world (Fromm 1964). 
Against Freud, however, Fromm wishes to pay greater recognition to the social bases of secondary narcissism, as well as to extend its application beyond problems of the mentally ill. More specifically, Fromm's aim is to deconstruct the narcissism of "normal" individuals, especially the social processes by which the narcissistic character becomes typical of many "normal" people in their symbiotic relatedness; so typical, indeed, that normalcy itself becomes pathological on a mass scale (Fromm 2010 [1991]).

\section{Narcissism as an Antecedent of Authoritarian Violence}

Implicit in Fromm's theorization of human behaviour is the notion that narcissism forces individuals to constantly evaluate and try to ensure the legitimacy - the rationality and morality — of their actions. However, following in the footsteps of Marx, Fromm suggests that the concrete standards by which actions are evaluated and to which they are adjusted usually derive from one's social existence (one's position within social space, as Bourdieu would put it) and the unfolding of the economic mode of production in particular. This means that the content of evaluations and the forms actions consequently take are anything but certain. Whilst, in other words, narcissistic urges inescapably set in motion the process of continuously assessing the legitimacy of one's own actions, there are no guarantees that engagement in this process will bring about objectively rational and moral outcomes. Individuals themselves, of course, tend to believe the reverse by mere dint of engaging in continuous selfevaluation, but this should be taken to reflect the distorting effect narcissistic urges may have on human perception and action; it turns out that narcissism may contribute to diluting the very process of reflection it causes. Below I consider Fromm's view of the mechanisms and contextual conditions that combine to narcissistically distort self-evaluation in ways that legitimate acceptance of, and even participation in, authoritarian violence against designated others.

Fromm first focuses on discourse and its narcissistic appeal; namely, its potential to call for actions through which individuals can experience a sense of strength without compromising their conscience. Thus, authoritarianism as manifestly expressed against third parties is legitimated by reference to ideological constructs that divide society into pairs of extremes along the lines of moralism: "'We' are admirable; 'they' are despicable. 'We' are good; 'they' are evil” (Fromm 1964:82). Indeed, the practice of violence may be framed in the pharisaic language of altruism, appearing to be a "well-meant attempt" to bring victims closer to higher 
principles (Fromm 1964). As Fromm is quick to recognize, however, stereotypes may only be validated retroactively. Just as "for a sadist the fact that he can kill a man proves that the killer is superior" (Fromm 1964:86), so too collective violence against weaker others is taken to attest the moral disposition and superiority of the violent collectivity itself. The attentive reader will have noticed Fromm's shift of reference from individuals to their membership in exclusive collectivities. This is entirely compatible with his concept of narcissism, not only because he deems it possible that personal narcissism may be transformed into group or social narcissism, but also because he views this transformation as likely to further undermine rational judgement.

[W]ithin the favoured group, everybody's personal narcissism is flattered, and the fact that millions of people agree with the statements makes them appear as reasonable. What the majority of people consider to be "reasonable" is that about which there is agreement, if not amongst all, at least amongst a substantial number of people; "reasonable", for most people, has nothing to do with reason, but with consensus. (Fromm 1964:79-80)

Might it not be argued, however, that the basic narcissistic need to survive is first and foremost what forces individuals to attribute far greater importance to themselves than they do to others? Fromm anticipates this point when he writes that violence may take a defensive, "reactive" form, which consists in biological "preservation, not destruction. It is not entirely the outcome of irrational passions, but to some extent of rational calculation" (Fromm 1964:25). And if, Fromm elaborates, personal survival tends to be tied to the vigour of a given collectivity, from a clan and an organization to the state and the nation, this is because individuals can survive grave physical dangers only if they organize themselves in groups (Fromm 1964:73). What mostly interests Fromm, however, goes beyond the strictly corporeal dimensions of narcissism and the defensive forms narcissistically driven violence may thus assume. He is rather preoccupied with the ontological facets of narcissism as they relate to "irrational" forms of violence under authoritarianism, even though, as we shall see below, they may resemble rational defensive measures. How is it, Fromm asks, that people may come to support authoritarianism and its violence when it is objectively against their moral values and even out of keeping with their instrumental interests? The question takes on additional urgency in light of the historical fact that individuals may prioritize the importance of a group over that of their very own lives, as when they participate in deadly wars on the behalf of authoritarian regimes; reality may be transmuted into illusions that serve the idolatry of the 
authoritarian group, but this does not inherently preclude facing actual corporeal dangers and intense fears of loss (Fromm 1964:78).

To explain the paradox, Fromm suggests that we focus on the psychosocial climate within which the ideological constructs of authoritarianism are formed and communicated. Particularly susceptible to authoritarian ideology, he thus argues, are those segments of the population that are experiencing an ontological void in their lives, such as having limited foreseeable hopes of upward socioeconomic mobility. This is because the negative compulsion to escape an unbearable situation usually renders people "unable to choose a line of action that could be a solution in any other but a fictitious sense" (Fromm 1994 [1941]:153). Fromm's preferred example is that of the lower middle classes in antebellum Germany. Whilst a member of the so-called "Frankfurt School" in the 1930s, Fromm undertook a detailed evaluation of previously gathered survey data on the political behaviour and consciousness of workers and employees under the Weimar Republic. (This, in fact, was the first public opinion survey ever to apply modern psychological methods to the investigation of political and electoral behaviour; Brunner 1994). Fromm's research question was as follows:

To what extent do German workers and employees have a character structure which is the opposite to the [then ascending] authoritarian idea of Nazism? And that implied still another question: To what extent will the German workers and employees, in the critical hour fight Nazism? (Fromm 1992 [1955]:148)

Much to his dismay, Fromm discovered a small degree of opposition to authoritarianism, which he attributed to widespread socioeconomic insecurities, themselves the outcome of mass unemployment, hyperinflation, and a grave crisis in the stock market (see Fromm 1984 [1929]). ${ }^{5}$

5. Fromm's work was not published at the time, possibly because of its terminological allegiance to Marxism. The coming of the Nazis to power in 1933 forced the Frankfurt School to emigrate to Columbia University in New York, and, according to Fromm's recollections in the mid-1970s, his former colleagues "became so frightened after they had come to America of being considered radicals that they began ... to suppress all words which sounded radical" (Funk 2000:101). An alternative explanation is that Fromm was not only pointing to the embarrassing existence of an "authoritarianism of the Left" (Burston 1991:110), but his attack on orthodox psychoanalytic theory and its deterministic obsession with the death instinct, the Oedipus complex, sexuality, and early childhood experiences had alienated the core leaders of the school. For them, to accept the centrality of the libidinal instincts was tantamount to affirming a built-in biological resistance to the repressive role of society. It comes as no surprise, from this perspective, that they went so far as to criticize Fromm repeatedly and relentlessly as a "revisionist" who preached no more than adaptation to the status quo (Ingleby 2006:xxiii). Under the pretext of financial shortage, Fromm's lifelong contract with the school was cancelled in 1939, and his reputation amongst the Left has yet to recover (Funk 2000; see also Rickert 1986). 
The specifics of this claim have been questioned empirically in recent years (see, e.g., Hamilton 1986, 1996; McLaughlin 1996, 2007), but this should not detract from Fromm's broader effort to highlight the centrality of the perpetual search for meaning and the desire for transcendence in human beings (McLaughlin 2007). "Psychological scarcity," Fromm ultimately proposes, commonly compels man to hate, to envy, or to submit (Fromm 1986 [1949]). Thus, states which fail to provide adequately for the majority of the populace manage to preempt the spread of dissatisfaction and necessitate attachment to their rule by cultivating a malignant type of narcissistic pride on a mass scale. Targeting weak or comparatively weaker out-groups as posing dangers to security serves to divert negative attention away from leaders and their role in generating or not resolving insecurities on the socioeconomic front, at the same time as providing the public with a concrete outlet onto which to transfer their anxieties, angers, and complexes. The latent function served by the violence which follows as a consequence Fromm calls "compensatory" (Fromm 1964:31).

As we saw earlier, however, Fromm believes that individuals never cease assessing the rationality and morality of their actions, and that the yardsticks against which actions are assessed vary according to the particular circumstances of the moment. It seems likely, moreover, that the frequency and depth of self-assessment increase with the practical, psychological, and moral weight of the actions under scrutiny. The successive concessions implicit in authoritarian ideologies are just such weighty actions, from bestowing the mandate to rule on powerful authorities, to consenting to the violent exclusion of others, to even placing oneself in great corporeal peril. Thus, despite an initial stage of concurrence, concessions are inevitably liable to regular and thorough testing against the contrary calls of lived reality. Order is bound to begin shattering as soon as subordinates grasp the rational incongruity of subordination and the immoral nature of the authority at issue.

An obvious resolution, and one which would chime with Fromm's focus on the ontological facets of narcissism as they relate to the human search for a clear conscience, is that ideologies are too difficult to abandon once one is drawn into their fallacy (see, e.g., Zerubavel 2006). Fromm chooses a different path, contending that the ever-present frightful prospect of men waking from their "customary half-slumber" (Fromm 1968:28) and breaking with the authority that controls them forces the latter to invent afresh "stories about the nobility of their cause, about defence against the threat to freedom, about revenge for bayoneted children, raped women, and violated honour" (Fromm 1964:19). All the while, a strong narcissistic quality is conferred upon collateral losses, the 
fact of which may thus lend itself to retrospective validation of authoritarian ideology. Here Fromm instances the elevation to heroes of those who died on the battlefield during the various European expeditions of conquest (Fromm 2007 [1976]:115-117). Holst-Warhaft writes in the same spirit that "mourning is not left to the bereaved, but taken over by the state as a national and civic duty." The memorials and cemeteries of the First World War, for example, romanticized self-sacrificial submission in the form of death, associating it with martyrdom and resurrection.

The belief that death in war imitated the Passion of Christ had a double benefit: it encouraged men to go to war, fearless of death (at least until they reached the front lines), and it helped fellow soldiers and families to accept the deaths of family members and friends. (Holst-Warhaft 2000:163)

\section{Resistance of the Weak and the Psychopolitics of Representation}

Thus far, I have endeavoured to address the legitimation of authoritarian violence by reference to ideological constructs that resonate with the deep-seated narcissistic need for social distinction. Attention has also been paid to the socioeconomic contextual conditions that boost the psychic appeal of authoritarian ideology, and to the legitimation of authoritarian ideology itself through evocation both of the violence already enacted in its name and the consensual support this violence enjoys amongst the public. In this section, the focus shifts to the ways in which the rational defensive actions of the targets of authoritarian violence — or, to be more precise, their rational defensive reactions — are represented in the public domain in such distorted ways as to bolster the apparent legitimacy of authoritarian ideology and of the violence that accompanies it.

Fromm argues that the targets of authoritarian violence often engage in acts of resistance, but doing so may only serve to reinforce the very stereotypes resistance is intended to upturn. In fact, overt struggles waged by the oppressed may work to increase the loyalty even of those not wholly identified with the oppressors. This is because defence and resistance are typically portrayed by the owners of the means of cultural production as irrational aggression, which in turn allows for the cloaking of authoritarian violence in "necessary protective measures" (Fromm 1994 [1941]). Not that praise for resistance to oppression is not relayed through mainstream channels of mediation, but it is comparatively scant and, what is worse, it may well operate to legitimate the powers that be (Fromm 1992 [1955]). The formation of the Greek nation-state is a useful example. With a view to uprooting nationalist public sentiments, 
intellectual pundits and folklorists co-opted to romanticize the heroes of the Greek struggle for liberation from four-hundred-year Ottoman occupation as the living embodiment of valour and patriotism. This coveted taxonomic category, however, excluded

those of their compatriots who continued to bear arms once that independence had been achieved, for by this time their activity was mostly directed not against the Turkish enemy but against the representatives of the Greek State. (Herzfeld 1986:60)

In fact, much like battles with opportunistic motives, antistate resistance was quickly described in official writings as brigandage. Perhaps the greatest irony is that guerrillas who might have challenged the authority of politicians but had died too early to pose grave and durable threats, could still be apotheosized. Although known to have sided with the Turks in search for personal gratification and power, "even that archenemy of the political establishment, Odhisseas Androutsos, appears on schoolroom posters to this day, resplendent in his Classical helmet" (Herzfeld 1986:60; see Xenakis 2006).

In any event, as Fromm notes, on most of those sparse occasions that praise for resistance to oppression occurs in the mainstream media of communication, it is only retrospective and resisters "have been dead for a long enough time - safely and sufficiently dead, that is" (Fromm 1992 [1955]:159). The point here is far more complex than selective memory or deliberate amnesia, forgetting to remember or remembering to forget. Whilst ensuring the dead a place in the collective memory of the living, fitting the codes of heroic sacrifice for the general good, symbols of glorification such as works of art, memorials, and museums must bear no relevance to current affairs (see Holst-Warhaft 2000). Unless so wished and orchestrated by powers of a superior order, people must not be able to take the grand revolutionary images of the past and recast them in the more familiar terms of local, lived experience. In Freudian language, acts of remembrance should not necessarily entail the transformation of "the impulsion to remember" into "the compulsion to repeat," a transference relationship of continuity with yesteryear (on which, see Praeger 1998). To this end, the necessity of resistant action is inextricably tied to the social particularities (indeed, curiosities) of a long-gone Zeitgeist. In the name of ethical thinking, whereby relativizing the exceptionalism attributed to given forms and spaces amounts to an abhorrent stance, the possibility is quashed that people draw connections and make predictions themselves, that they realize the hegemonic nature of their submission and its evil consequences for the self and others (Scheper-Hughes 2002). Ethical thinking becomes a euphemism for its own negation. At 
once mystified and exorcized, the past can hardly trigger nostalgic retrospection, self-doubt and guilt, or visionary exercises.

\section{NARCissism ANd Authoritarian Leadership}

Unless one subscribes to a Foucauldian conceptualization of power as a "kind of empty structure, stripped of any agents, interests, or grounding" (Garland 1990:170), then the question emanating from the preceding analysis concerns the underpinnings of authoritarian leadership. If, as Fromm suggests, the narcissistic need to align action with the requirements of a clear conscience is a universal constant, then how is it possible for elites to govern in an authoritarian manner?

Fromm is adamant that the most horrific facets of history are animated by material relations of power. Wars, he explains, commonly result from decisions by political, military, and business leaders for the sake of gaining territory, natural resources, and advantages in trade (Fromm, 1964). In his extensive psychobiography of Hitler, for example, Fromm identifies the infamous "mad streak" of his analysand, but concludes that "Hitler was sane enough to pursue his aims purposefully and — for a while - successfully" (Fromm 1984 [1973]:572). This is not dissimilar to the argument by historian A.J.P. Taylor (1961) that Hitler went to war, in good part, as a means by which to seek lost German territory, hence he was not so different from other political leaders of his time. (Indeed, fixing the guilt of the Second World War on Hitler's supposed madness may be viewed, in and of itself, as a political act underlaid with narcissistic motives, for it serves to obscure the evidence of genocidal precepts and practices in various parts of antebellum Europe, to conceal how the diplomatic blunders of Western statesmen themselves contributed to the outbreak of the war, to acquit the German people of the atrocities of the Nazi regime, to absolve Germany's former allies of blame, and even to idealize how the United States came to be involved in the warfare; see Taylor 1961; Mazower, 1998). ${ }^{6}$

And yet, contra C. Wright Mills (1959) and his otherwise "masterful" analysis of conscious manipulation for private and in-group gain,

6. A recent example of the politicized application of psychological profiling to Hitler and other, contemporary leaders can be found in Post (2004). In a chapter devoted to "Narcissism and the Charismatic Leader-Follower Relationship," Post applies his genealogy of narcissistic destructiveness to the relationship between, on the one hand, such "mirror-hungry" leaders as Adolph Hitler, Fidel Castro, Ayatollah Khomeini, Saddam Hussein, and Osama bin Laden, and, on the other hand, such "ideal-hungry" followers as the Germans of the Nazi era, and the Cuban people and the Arabs of our days. America, by contrast, is presented as a nation of rightful aggressors led by "reparative," as opposed to "destructive," authorities. 
Fromm holds that the elites are not consciously driven by an overwhelming greed for power and pay. "To be sure, such motives exist, too; but the people in whom this is the all-consuming motive are the exception rather than the rule" (Fromm 2006 [1962]:83). For Fromm, inherent to the acquisition and exercise of power is the universal narcissistic need to keep one's own conscience satisfied, which is why governing elites tend to legitimate their position and power to themselves and to their immediate staff at least as much as to the masses they govern. To take the example of Hitler again, a careful reading of Mein Kampf reveals not only his "conscious" effort to manipulate the people by presenting them with an oversimplified image of the one great Enemy, but also his own passionate immersion in the lore so created (see Fromm 1984 [1973]; also Žižek 2004). Crucially, in its effects, having and retaining a good narcissistic conscience is also a matter of practical convenience, for it provides authoritarian elites with "the certainty and freedom from doubt which is so impressive to the average person" (Fromm 1964:76). By way of a feedback loop, moreover, popular success furthers elites' selfperceptions of righteousness (Fromm 1964).

As in the case of lay people, Fromm elaborates that the standards by which elites gauge the legitimacy of their ruling follow directly from their socioeconomic existence.

They consider their way of organisation and the values that are implied in it as being in "the best interests of man"; they have a picture of human nature which makes this assumption plausible; they are hostile to any idea or system which questions or endangers their own system; they are against disarmament if they feel that their organisations are threatened by it; they are suspicious and hostile of a system in which their class has been replaced by a different and new class of managers. Consciously, they honestly believe that they are motivated by patriotic concern for their country, duty, moral and political principles, and so on.... The motivating factor is that their social function forms their consciousness, and hence their conviction that they are right, that their aims are justified and, in fact, beyond doubt. (Fromm 2006 [1962]:83)

Fromm's theory of elite narcissism has inspired recent attempts to theorize leadership of conglomerates and other large corporations (Maccoby 2003), as well as the politics of criminal justice policy-making under conditions of neoliberal capitalism (Cheliotis 2009; 2010b), with attention being drawn, for example, to the tendency amongst elites to ignore opinions and even expert evidence that point to the destructive nature of their decisions. That said, Maccoby (2003) has drawn inspiration from Fromm also to demonstrate that narcissistic leadership need not 
necessarily be authoritarian or otherwise damaging. Whilst this observation falls beyond the scope of this article, it raises the broader question of how Fromm theorizes the possibility of channelling narcissism into objectively positive pursuits.

\section{Concluding Remarks: "Benign NarCissism"}

Against the orthodox Freudian conceptualization of narcissism as innately fixed towards the actualization of distinction through authoritarianism and destructiveness, Fromm argues that it is possible to divert narcissistic cathexes into a common normative commitment to human solidarity.

Fromm calls for what he names "benign narcissism." In this case, the object of narcissistic attachment is focused on achievement, or, more precisely, on the effort made to achieve a given goal. This is because industry facilitates connection to external reality and solidarity with one's fellow human beings. In particular, "[o]ne who has learned to achieve cannot help acknowledging that others have achieved similar things in similar ways-even if his narcissism may persuade him that his own achievement is greater than that of others" (Fromm 1964:77). Fromm makes a similar case with regard to social or group narcissism, suggesting that the collectivity may help individuals maintain a narcissistic equilibrium and direct their passion towards the pursuit of progressive ideals and aims. For instance, "[i]f the object of group narcissism is an achievement...[t]he very need to achieve something creative makes it necessary to leave the closed circle of group solipsism and to be interested in the object it wants to achieve" (Fromm 1964:78).

Fromm's initial idea is that the process of striving for achievement is "benign" in its narcissistic effects, for it works to reduce "the biologically necessary degree of narcissism...to the degree of narcissism that is compatible with social co-operation" (Fromm 1964:73). Eventually, however, Fromm deems it futile to try to impose quantitative controls upon the "narcissistic core," an observation that forces him to posit benign narcissism as subject solely to a prior qualitative change in the object of attachment. "Even without reducing narcissistic energy in each person, the object could be changed," he writes (Fromm 1964:90). The immediate question, at any rate, is how to ensure that the object of narcissistic attachment be reoriented towards the "benign" process of striving for achievement, whether individually or collectively.

Tempting answers may be found, amongst others, in Hannah Arendt's well-known treatise on political action. Starting from the premise 
that the "urge to self-display" is fundamental to human nature, Arendt uses the example of the ancient Greek city-state (the polis) to illustrate that, under the ethos and the laws of participatory democracy, phenomena such as council participation, civil disobedience, and even revolution can essentially be read as manifestations of a politically healthy or benign narcissism on the part of the individuals involved. In The Human Condition, Arendt suggests that the aim of the polis was to multiply the occasions to win "immortal fame," i.e., to allow one to show in deed and word who he was in unique distinctness.

The organisation of the polis ... is a kind of organised remembrance. It assures the mortal actor that his passing existence and fleeting greatness will never lack the reality that comes from being seen, being heard, and, generally, appearing before an audience of fellow men.... According to this self-interpretation, the political realm rises directly out of acting together, the "sharing of words and deeds." Thus, action not only has the most intimate relationship to the public part of the world common to us all, but is the one activity which constitutes it. (Arendt 1998 [1958]:197-198)

In other words, insofar as the existence of an open public sphere depends upon the human condition of plurality it itself purports to promote and preserve, then it also enables individuals to satisfy their natural narcissistic tendencies, whilst at the same time preventing them from relating to others as idealized self-objects (see Brunner 1994).

One cannot help stressing at this point that the emergence as well as the benefits of narcissistically driven political action are inherently precarious. Arendt herself accepts that the open public sphere of Athenian antiquity could hardly be seen as a mathematical constant across spatial and temporal spans. As a matter of fact, it is doubtful even whether the paradigm of the polis has ever practically been as inclusive and participatory as historicized in various scholarly analyses and folk parlance.

Although all men are capable of deed and word, most of them - like the slave, the foreigner, and the barbarian in antiquity, like the labourer or craftsman prior to the modern age, the jobholder or businessman in our world - do not live in [the open space of appearance that is the polis]. (Arendt 1998 [1958]:199)

Whatever hope for interrupting or diverting the chains of unfortunate events, Arendt eventually concludes, seems to rest not so much with the sociopolitical habitats already in place, but with "the one miracle-working faculty of man" to ebb away unexpectedly from almighty regimes and make new beginnings (Arendt 1998:246). 
Yet spontaneity and unpredictability should not be overstated, either. The existence and significance of human individuals are hard to distinguish fully from the social and historical context in which they are created, and of which individuals themselves are parts. For example, one should expect people to be more likely to oppose powerful regimes insofar as doing so serves the best way of validating the self in the eyes of "significant others" with whom they interact. Or, to put it differently, the occurrence of narcissistic resistance is contingent upon the existence of unconventional significant others. For one's narcissistic urge to be channelled into the avenues of a resistance pursuant to the objective needs of society and of individuals themselves, however, significant others must also espouse truly progressive values and beliefs. As Fromm himself observes, significant others are only the representatives and agents of broader authority structures - including, of course, exclusive narcissistic groups (see Fromm 1978[1932]).

It is with this in mind that Fromm proceeds to revisit the preconditions and the meaning of the idea of achievement as the object of benign narcissism, situating them outside the ethical spheres of private individuals, the family, particular cohorts of the general population, or localist political systems. Fromm now recommends the all-inclusive principles of the moral philosophy of humanism, which allow for freeing oneself from "the ties of blood and soil, from his mother and his father, from special loyalties to state, class, race, party, or religion" (Fromm 1992[1955]:165).

If the individual could experience himself primarily as a citizen of the world, and if he could feel pride in mankind and in its achievements, his narcissism would turn towards the human race as an object, rather than to its conflicting components. (Fromm 1964:90)

This should not be mistaken for a plea for uniformity. Rather, Fromm views the foundation of a "richer and broader human culture" as consisting in the accentuation of difference in the sense of cultivating the positive sides of individual peculiarities (Fromm 1943:114-115; quoted by Wilde 2004). This analytical move allows him to level one final criticism against the Freudian concept of secondary narcissism, particularly against the "almost mechanical alternative between ego-love and objectlove." Whereas, according to Freud, "the more love I turn towards the outside world, the less love is left for myself, and vice versa," Fromm contends that "[i]f it is a virtue to love my neighbour as a human being, it must be a virtue - and not a vice - to love myself, since I am a human being, too. There is no concept of man in which I am not included" (Fromm 2000 [1956]:54; see further Cheliotis 2010c). 
In a period of global economic crisis and rising tensions in societies across the world, Fromm's account of authoritarianism and his vision of the safety valve of humanism are particularly prescient and deserve a new audience.

\section{REFERENCES}

Arendt, H. 1998 [1958]. The Human Condition. Chicago, IL: The University of Chicago Press.

Benjamin, J. 1988. The Bonds of Love: Psychoanalysis, Feminism, and the Problem of Knowledge. New York: Pantheon.

Blumer, H. 1969. Symbolic Interactionism. Englewood Cliffs, NJ: Prentice-Hall.

Bourdieu, P. 2005. The Social Structures of the Economy. Cambridge: Polity Press.

1989. Social space and symbolic power. Sociological Theory 7(1):18-26.

Brunner, J. 1994. Looking into the hearts of the workers, or: How Erich Fromm transformed critical theory into empirical research. Political Psychology 15(4):631-654.

Burston, D. 1991. The Legacy of Erich Fromm. Cambridge, MA: Harvard University Press.

Chancer, L.S. 1992. Sadomasochism in Everyday Life: The Dynamics of Power and Powerlessness. New Brunswick, NJ: Rutgers University Press.

Cheliotis, L.K. 2011. For a Freudo-Marxist critique of social domination: Rediscovering Erich Fromm through the mirror of Pierre Bourdieu. Journal of Classical Sociology 11(4):438-461.

2010a. The sociospatial mechanics of domination: Transcending the "exclusion/inclusion" dualism. Law \& Critique 21(2):131-145.

2010b. Governare attraverso lo specchio: Neoliberismo, managerialismo e la psicopolitica del controllo della devianza. Studi sulla questione criminale 5(3):47-94.

2010c. Narcissism, humanism and the revolutionary character in Erich Fromm's work. Pp. 36-58 in L.K. Cheliotis, ed., Roots, Rites and Sites of Resistance: The Banality of Good. Basingstoke: Palgrave Macmillan. 2009. Governing through the Looking-Glass: Perception, Morality and Neoliberal Penality. Unpublished Ph.D. Thesis, University of Cambridge.

Chodorow, N. 1978. The Reproduction of Mothering: Psychoanalysis and the Sociology of Gender. Berkeley, CA: University of California Press.

Craib, I. 1990. Psychoanalysis and Social Theory: The Limits of Sociology. Amherst, MA: The University of Massachusetts Press.

Durkheim, É. 1964 [1893]. The Division of Labour in Society. New York: Free Press. 
Elliott, A. and C. Lemert. 2006. The New Individualism: The Emotional Costs of Globalisation. London and New York: Routledge.

Fromm, E. 2010 [1991]. The Pathology of Normalcy. New York: American Mental Health Foundation Books. 2007 [1976]. To Have or to Be? London and New York: Continuum. 2006 [1962]. Beyond the Chains of Illusion: My Encounter with Marx and Freud. New York: Continuum. 2000 [1956]. The Art of Loving. New York: Harper Perennial.

1992 [1955]. The Dogma of Christ and Other Essays on Religion, Psychology, and Culture. New York: Henry Holt \& Company.

1994 [1941]. Escape from Freedom. New York: Henry Holt \& Company. 1986 [1949]. Man for Himself. London: Ark.

1984 [1973]. The Anatomy of Human Destructiveness. Harmondsworth: Penguin.

- 1984 [1929]. The Working Class in Weimar Germany: A Psychological and Sociological Study. Leamington Spa: Berg.

1978 [1932]. The method and function of an analytic social psychology. Pp. 477-496 in A. Arato and E. Gebhardte, eds., The Essential Frankfurt School Reader. New York: Urizen Books.

1968. The Revolution of Hope: Toward a Humanized Technology. New York: Harper \& Row.

1964. The Heart of Man: Its Genius for Good and Evil. New York: Harper \& Row.

Funk, E. 2000. Erich Fromm: His Life and Ideas: An Illustrated Biography. New York: Continuum.

Funk, R. 1982 [1978]. Erich Fromm: The Courage to be Human. New York: Continuum.

Gaitanidis, A. and P. Curk, eds. 2007. Narcissism: A Critical Reader. London: Carnac.

Garfinkel, H. 1967. Studies in Ethnomethodology. Englewood Cliffs, NJ: Prentice-Hall.

Garland, D. 1990. Punishment and Modern Society: A Study in Social Theory. Oxford: Clarendon Press.

Hall, S. 1997. The work of representation. Pp. 13-74 in S. Hall, ed., Representation: Cultural Representations and Signifying Practices. London: Sage.

Hamilton, R.F. 1996. The Social Misconstruction of Reality: Validity and Verification in the Scholarly Community. New Haven, CT: Yale University Press.

1986. Review of Erich Fromm, The Working Class in Weimar Germany. Society March/April: 82-83.

Herzfeld, M. 1986. Ours Once More: Folklore, Ideology, and the Making of Modern Greece. New York: Pella.

Holst-Warhaft, G. 2000. The Cue for Passion: Grief and its Political Uses. Cambridge, MA and London: Harvard University Press. 
Ingleby, D. 2006. Introduction to the second edition. Pp. xvi-liii in E. Fromm The Sane Society. London and New York: Routledge.

Jacoby, M. 1985. Individuation \& Narcissism: The Psychology of Self in Jung \& Kohut. Hove and New York: Brunner-Routledge.

Lasch, C. 1979. The Culture of Narcissism: American Life in an Age of Diminishing Expectations. New York and London: W.W. Norton \& Company.

Layton, L., N.C. Hollander, and S. Gutwill, eds. 2006. Psychoanalysis, Class and Politics: Encounters in the Clinical Setting. London and New York: Routledge.

Lévi-Strauss, C. 1966 [1962]. The Savage Mind. Chicago: The University of Chicago Press.

Lowen, A. 1997. Narcissism: Denial of the True Self. New York: Touchstone.

Maccoby, M. 2003. The Productive Narcissist: The Promise and Peril of Visionary Leadership. New York: Broadway Books.

1981. The Leader: A New Face for American Management. New York: Simon and Schuster.

Mazower, M. 1998. Dark Continent: Europe's Twentieth Century. London: Allen Lane.

McLaughlin, N. 2007. Escape from evidence? Popper, social science, and psychoanalytic social theory. Dialogue 46(4):761-780. 2001. Optimal marginality: Innovation and orthodoxy in Fromm's revision of psychoanalysis. Sociological Quarterly 42(2):271-288. 1999. Origin myths in the social sciences: Fromm, the Frankfurt School and the emergence of critical theory. Canadian Journal of Sociology 24(1):109-139.

1996. Nazism, nationalism, and the sociology of emotions: Escape From Freedom revisited. Sociological Theory 14(3):241-261.

Mills, C. Wright 1959. The Sociological Imagination. New York: Oxford University Press.

Morrison, A.P. 1989. Shame: The Underside of Narcissism. New York and London: The Analytic Press.

Post, J.M. 2004. Leaders and their Followers in a Dangerous World: The Psychology of Political Behaviour. Ithaca, NY: Cornell University Press.

Praeger, J. 1998. Presenting the Past: Psychoanalysis and the Sociology of Misremembering. Cambridge, MA and London: Harvard University Press.

Rickert, J. 1986. The Fromm-Marcuse debate revisited. Theory and Society 15(3):351-400.

Scheff, T.J., Jr. 2006. Goffman Unbound! A New Paradigm for Social Science. London: Paradigm Publishers. 
Scheper-Hughes, N. 2002. The genocidal continuum: Peace-time crimes. Pp. 29-47 in J. Mageo, ed., Power and the Self. Cambridge: Cambridge University Press.

Schwartz-Salant, N. 1982. Narcissism and Character Transformation: The Psychology of Narcissistic Character Disorders. Toronto: Inner City Books.

Sennett, R. 1977. The Fall of Public Man. New York: Knopf.

Smelser, N.J. 1998. The Social Edges of Psychoanalysis. Berkeley, CA: University of California Press.

Steinmetz, G. 2006. Bourdieu's disavowal of Lacan: Psychoanalytic theory and the concepts of "habitus" and "symbolic capital." Constellations 13(4):445-464.

2005. Sociology: Scientific authority and the transition to post-Fordism: The plausibility of positivism in U.S. sociology since 1945. Pp. 275-323 in G. Steinmetz, ed., The Politics of Method in the Human Sciences: Positivism and its Epistemological Others. Durham, NC and London: Duke University Press.

Sugerman, S. 1976. Sin and Madness: Studies in Narcissism. Philadelphia: Westminster Press.

Taylor, A.J.P. 1961. The Origins of the Second World War. Middlesex: Penguin Books.

Vetlesen, A.J. 1994. Perception, Empathy, and Judgment: An Inquiry into the Preconditions of Moral Performance. University Park, PA: Penn State Press.

Wacquant, L. 1992. Toward a social praxeology: The structure and logic of Bourdieu's sociology. Pp. 1-59 in P. Bourdieu and L.J.D. Wacquant, An Invitation to Reflexive Sociology. Cambridge: Polity.

Wilde, L. 2004. Erich Fromm and the Quest for Solidarity. Basingstoke: Palgrave Macmillan.

Xenakis, S. 2006. International Norm Diffusion and the Development of Greek Policy against Organised Crime, 1989-2001. Unpublished Ph.D. Thesis, University of Oxford.

Zerubavel, E. 2006. The Elephant in the Room: Silence and Denial in Everyday Life. Oxford: Oxford University Press.

Žižek, S. 2004. Iraq: The Borrowed Kettle. London: Verso.

Leonidas K. Cheliotis is Lecturer and Deputy Director of the Centre for Criminal Justice at the School of Law, Queen Mary, University of London, UK. He is an Associate Editor of the European Journal of Criminology, and the editor of The Arts of Imprisonment: Control, Resistance and Empowerment (2012), Crime and Punishment in Contemporary Greece: International Comparative Perspectives (2011, with Sappho Xenakis), and Roots, Rites and Sites of Resistance: The 
Banality of Good (2010). He is currently working on a monograph provisionally entitled The Punitive Heart: Neoliberal Capitalism and the Psychopolitics of Crime Control.

1.cheliotis@qmul.ac.uk 